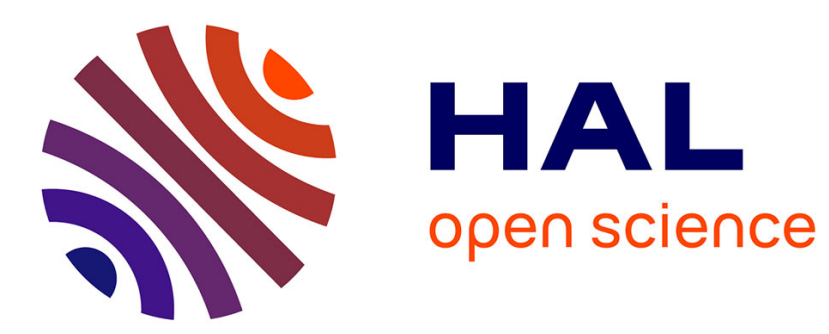

\title{
Greenhouse soil solarization: effect on weeds, nematodes and yield of tomato and melon
}

Vincenzo Candido, Trifone d'Addabbo, Martino Basile, Donato Castronuovo, Vito Miccolis

\section{- To cite this version:}

Vincenzo Candido, Trifone d'Addabbo, Martino Basile, Donato Castronuovo, Vito Miccolis. Greenhouse soil solarization: effect on weeds, nematodes and yield of tomato and melon. Agronomy for Sustainable Development, 2008, 28 (2), pp.221-230. hal-00886406

\section{HAL Id: hal-00886406 https://hal.science/hal-00886406}

Submitted on 1 Jan 2008

HAL is a multi-disciplinary open access archive for the deposit and dissemination of scientific research documents, whether they are published or not. The documents may come from teaching and research institutions in France or abroad, or from public or private research centers.
L'archive ouverte pluridisciplinaire HAL, est destinée au dépôt et à la diffusion de documents scientifiques de niveau recherche, publiés ou non, émanant des établissements d'enseignement et de recherche français ou étrangers, des laboratoires publics ou privés. 


\title{
Greenhouse soil solarization: effect on weeds, nematodes and yield of tomato and melon
}

\author{
Vincenzo CANDIDO $^{1}$, Trifone D’AdDABBo ${ }^{2 *}$, Martino BASILE $^{2}$, Donato CASTRONUOvo ${ }^{3}$, Vito Miccolis ${ }^{1}$ \\ ${ }^{1}$ Dipartimento di Scienze dei Sistemi Colturali, Forestali e dell'Ambiente, Università degli Studi della Basilicata, Via dell'Ateneo Lucano, 10 - 85100, Potenza, \\ Italy \\ ${ }^{2}$ Istituto per la Protezione delle Piante - CNR, Via G. Amendola 122/D, Bari, Italy \\ ${ }^{3}$ Dipartimento Tecnico-Economico, Università degli Studi della Basilicata, Via dell'Ateneo Lucano, 10 - 85100, Potenza, Italy
}

(Accepted 26 October 2007)

\begin{abstract}
Phase-out of methyl bromide and health concerns related to the use of pesticides are increasing the interest in alternative control strategies. Soil solarization is an effective, safe and cheap technique for the control of soil-borne pathogens and weeds. However, knowledge of the long-term effects of solarization, as well as of repeated solarization cycles, is scarce. Such knowledge should in particular help to minimize the number of solarization treatments. Therefore, we tested the residual effect of a single solarization treatment and the effects of two or three solarization cycles on root-knot nematodes, weeds and crop yield for three years on greenhouse-grown tomato and melon. Soil solarization was applied for either one, two or three consecutive years on a soil infested by the root-knot nematode Meloidogyne javanica and many annual and perennial weed species. An untreated soil was used as a control. At the end of each crop cycle yield parameters were recorded, weeds were identified and counted, and nematode infestation was evaluated. Our results show that a single solarization treatment significantly increased yields by $+116 \%$, and strongly reduced nematode infestation of $-99 \%$ of infested plants and of $-98 \%$ of the root gall index in the following melon crop. It also suppressed annual weed emergence three years later. Plant yields from two- and three-year solarized soil were always higher than nonsolarized control: $+284 \%$ and $+263 \%$, respectively, for tomato, and $+162 \%$ and $+368 \%$, respectively, for melon. Further, twoand three-year solarization treatments almost completely suppressed the infestation of the $M$. javanica nematode in tomato, and reduced the nematode effect in melon by $-86 \%$ and $-79 \%$, respectively. Repeated solarization treatments also resulted in a high reduction of emergence of most weed species in all crop cycles. A single soil solarization treatment was shown to be effective for a long-term sustainable management of weeds, whereas the time-limited effectiveness against root-knot nematodes can be enhanced through two- or three-year repeated treatments.
\end{abstract}

solarization / nematodes / weeds / yield / tomato / melon

\section{INTRODUCTION}

Root-knot nematodes (Meloidogyne spp.) and weeds can cause heavy yield losses to many crops. Control of these pests is generally based on chemical treatments, but environmental and health hazards due to the extensive use of pesticides are forcing growers to rely on nonchemical pest management approaches (Katan, 1999). Soil solarization is a cost-saving and environmentally safe nonchemical soil disinfestation method that, under appropriate conditions, can ensure an effective control of a wide range of pathogens, weeds and arthropod pests (Camprubi et al., 2007; Stapleton, 2000). Other soil-heating treatments have been demonstrated to be as effective as solarization for the control of soil-borne diseases and weeds (Luvisi et al., 2006; Kolberg and Wiles, 2002), but are more expen-

* Corresponding author: t.daddabbo@ba.ipp.cnr.it sive and difficult to use for growers. Soil temperature increase caused by solarization must be sufficiently high and prolonged to cause irreversible damage to most soil-borne pathogens (Nico et al., 2003). Therefore, this technique is particularly suitable for the Mediterranean climate, where the occurrence of high summer temperatures can ensure an effective control of fungi, nematodes and weeds (Shlevin et al., 2003; Oka et al., 2007; Roe et al., 2004).

Evaluation of the persistence of soil solarization effects is particularly useful in intensive greenhouse cropping systems in Southern Italy, where short intervals between crops necessitate the need to reduce as much as possible the number of solarization treatments by extending their residual effects. Longterm effects of soil solarization were previously investigated mostly on soil-borne fungal pathogens in the field (Freeman et al., 1990; Tjamos and Paplomatas, 1988), whereas little information is available on the residual effect of solarization 


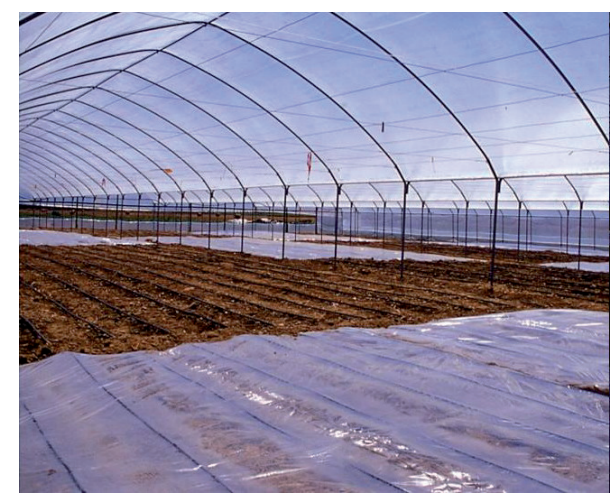

Figure 1. Solarization treatment in the metal-plastic greenhouse.

treatment on weeds and phytoparasitic nematodes in the greenhouse.

Solarization repeated for two or more consecutive years could improve the effectiveness of thermal treatment on heatresistant weed species or on root-knot nematodes (Meloidogyne spp.), that easily survive and reinfest the soil after a single solarization treatment (Rubin and Benjamin, 1983; Stapleton and DeVay, 1995).

A three-year experiment was undertaken to investigate (a) the long-term effect of a single solarization treatment and (b) the effect of solarization repeated for two or three consecutive years on root-knot nematodes, weeds and yield parameters in a greenhouse tomato - melon succession in Southern Italy.

\section{MATERIALS AND METHODS}

The experiment was undertaken in a metal-plastic $(200-\mu \mathrm{m}-$ thick low-density polyethylene transparent film) greenhouse located in Metaponto (40 $20^{\prime} \mathrm{N}$; $\left.16^{\circ} 48^{\prime} \mathrm{E}\right)$ in Southern Italy (Fig. 1). The alkaline ( $\mathrm{pH} 8.4$ ) sandy soil was heavily infested (3.1 eggs and juveniles $\mathrm{cm}^{-3}$ soil) by the root-knot nematode Meloidogyne javanica (Treub) Chitw.

On 23 July 1998 the soil was ploughed at $40 \mathrm{~cm}$ depth, uniformly rotavated and irrigated to field capacity at the same depth through a drip irrigation system with dripper lines $0.5 \mathrm{~m}$ apart and emitters $\left(3 \mathrm{~L} \mathrm{~h}^{-1}\right.$ water flow rate) spaced $0.20 \mathrm{~m}$ from each other. The soil surface was then divided into 16 plots $(6 \times 4 \mathrm{~m})$, spaced $1 \mathrm{~m}$ apart and grouped into four blocks. The surface of 12 plots, 3 in each block, was then covered with a low-density polyethylene (LDPE) $50-\mu \mathrm{m}$-thick transparent film and solarized for 79 days (from 24 July to 11 October 1998) in closed greenhouse conditions. In summer 1999 the solarization treatment was repeated on 8 of the plots solarized in the previous year, 2 in each block, covering the soil surface with an ethylene-vinyl acetate (EVA) $30-\mu$ m-thick transparent plastic film for 37 days, starting from 17 July. In 2000 only 4 plots, one in each block, were solarized with EVA film (as before) for 34 days, also starting from 17 July. In 1999 and 2000 LDPE, currently used for solarization in the Metaponto area, was replaced by a more thermally efficient EVA film (Russo et al., 2005) with the aim of shortening the solarization length and allowing cultivation of an autumn tomato crop.
Therefore, four experimental treatments, arranged in a complete randomized block design, were finally provided: nonsolarized soil, soil solarized only in 1998, soil solarized consecutively in 1998 and 1999 and soil solarized for three consecutive years (1998, 1999 and 2000).

After solarization in 1998, melon (Cucumis melo L. var. reticulatus Naud.) cv Baggio F1 was cultivated from 3 March 1999 to 8 July 1999. In 1999 and 2000 tomato (autumnwinter) and melon (spring-summer) were cultivated after solarization. Tomato (Lycopersicon esculentum Mill.) cv Naxos was transplanted on 28 August 1999 and 24 August 2000 and uprooted on 4 January 2000 and 26 January 2001, respectively. In 2000, melon cv Baggio F1 was transplanted on 14 March and cultivated until 26 June, whereas in 2001, cv Drake F1 was directly sown on 23 March and uprooted on 15 July. Tomato was transplanted in rows $1 \mathrm{~m}$ apart $\left(3.3\right.$ plants $\left.\mathrm{m}^{-2}\right)$, and melon was transplanted or sown in rows $2 \mathrm{~m}$ apart $(0.5$ plants $\mathrm{m}^{-2}$ ). Soil was left undisturbed after each solarization, mulched with a 50- $\mu$ m-thick black LPDE film during each crop cycle and slightly rotavated only at its end. All selected tomato and melon cultivars were reported as being susceptible to $M$. javanica.

Soil temperatures were monitored at 30 -min intervals during each solarization period. In 1998, temperatures at 5, 20 and $35 \mathrm{~cm}$ depth were recorded by a geothermograph (Salmoiraghi Instruments, Milan, Italy), whereas in 1999 and 2000, PT-100 probes and a CR-10X data-logger (Campbell Scientific, Inc., USA) were used to record soil temperatures at 10, 20 and $30 \mathrm{~cm}$ depth.

At the end of each crop cycle, number and weight of marketable fruits, average fruit weight and soluble solids content ( ${ }^{\circ}$ Brix) were assessed on samples taken from 3- or $12-\mathrm{m}^{2}$ sampling areas, for tomato and melon, respectively. Plants infected by $M$. javanica were counted and percent infestation was calculated for each plot. Nematode infestation on crop roots (root gall index) was estimated on 10 tomato and 6 melon plants plot $^{-1}$, according to a $0-5$ scale in which $0=$ no galls, $1=1$ to 2 galls, $2=3$ to 10 galls, $3=11$ to 30 galls, $4=31$ to 100 galls and $5=>100$ galls (Taylor and Sasser, 1987). After each solarization treatment and at the end of each crop cycle weeds were counted and classified from a $2-\mathrm{m}^{2}$ sampling area in the center of each plot and from the nonmulched soil between the rows. Weed biomass was completely removed from the soil after each observation.

Since the solarization treatment performed in 1998 differed from those performed in 1999 and 2000 in film type and thickness and in duration, the effect of the 1998 treatment was distinguished from those of the 1999 and 2000 treatments, comparing data from plots treated only in 1998 with those from untreated soil separately. Weed and nematode data were statistically analyzed after $\mathrm{L}_{n}(\mathrm{x}+1)$ transformation for homogenization of error variances. The Student's $t$ test or ANOVA were followed by mean comparison tests (Fisher's Least Significant Difference Test at $P \leqslant 0.05)$. 

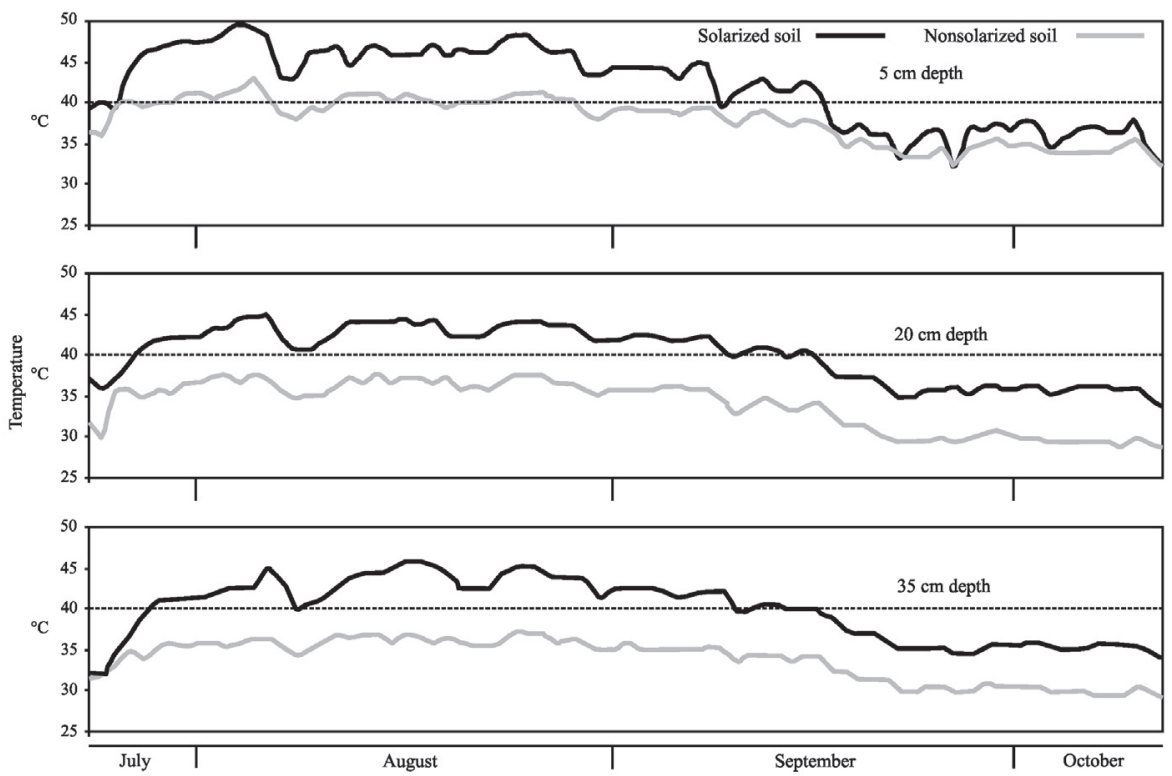

Figure 2. Daily mean soil temperatures at 5, 20 and $35 \mathrm{~cm}$ depth during solarization in 1998.
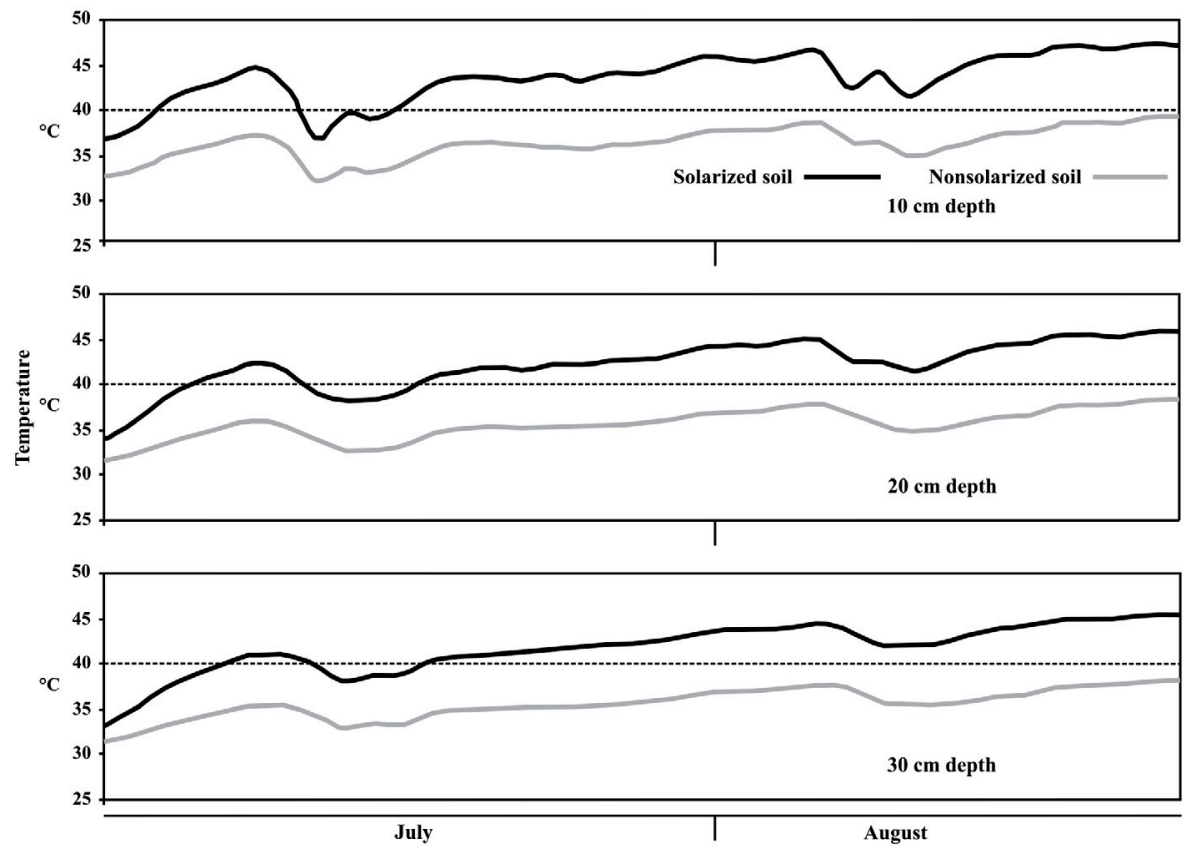

Figure 3. Daily mean soil temperatures at 10, 20 and $30 \mathrm{~cm}$ depth during solarization in 1999 .

\section{RESULTS AND DISCUSSION}

\subsection{Effect on soil temperatures}

During solarization in 1998 average daily soil temperatures were 41.9 and $37.8{ }^{\circ} \mathrm{C}$ at $5 \mathrm{~cm}$ depth and 39.9 and $33.6{ }^{\circ} \mathrm{C}$ at $20 \mathrm{~cm}$ depth, respectively, in solarized and nonsolarized soil (Fig. 2). Mean daily values at $35 \mathrm{~cm}$ depth were similar to $20 \mathrm{~cm}$ depth, but daily excursions were less pronounced (data not shown). Soil temperature differences between solar- ized and nonsolarized soil were larger during the first 40 days of solarization and decreased after the first decade of September. Maximum temperatures, occurring in the first (5 and 20 $\mathrm{cm})$ or the third $(30 \mathrm{~cm})$ week of August, were 59 and $46{ }^{\circ} \mathrm{C}$ $(5 \mathrm{~cm}), 49$ and $40{ }^{\circ} \mathrm{C}(20 \mathrm{~cm})$ and 49 and $39^{\circ} \mathrm{C}(35 \mathrm{~cm})$, respectively, in solarized and nonsolarized soil. In 1999, daily soil average temperature was $43.6,41.6$ and $40.3{ }^{\circ} \mathrm{C}$ in solarized soil and $36.4,35.2$ and $34.3{ }^{\circ} \mathrm{C}$ in nonsolarized soil, respectively, at 10, 20 and $30 \mathrm{~cm}$ depth (Fig. 3). The difference between treated and untreated soil was on average 7.1, 6.4 and 

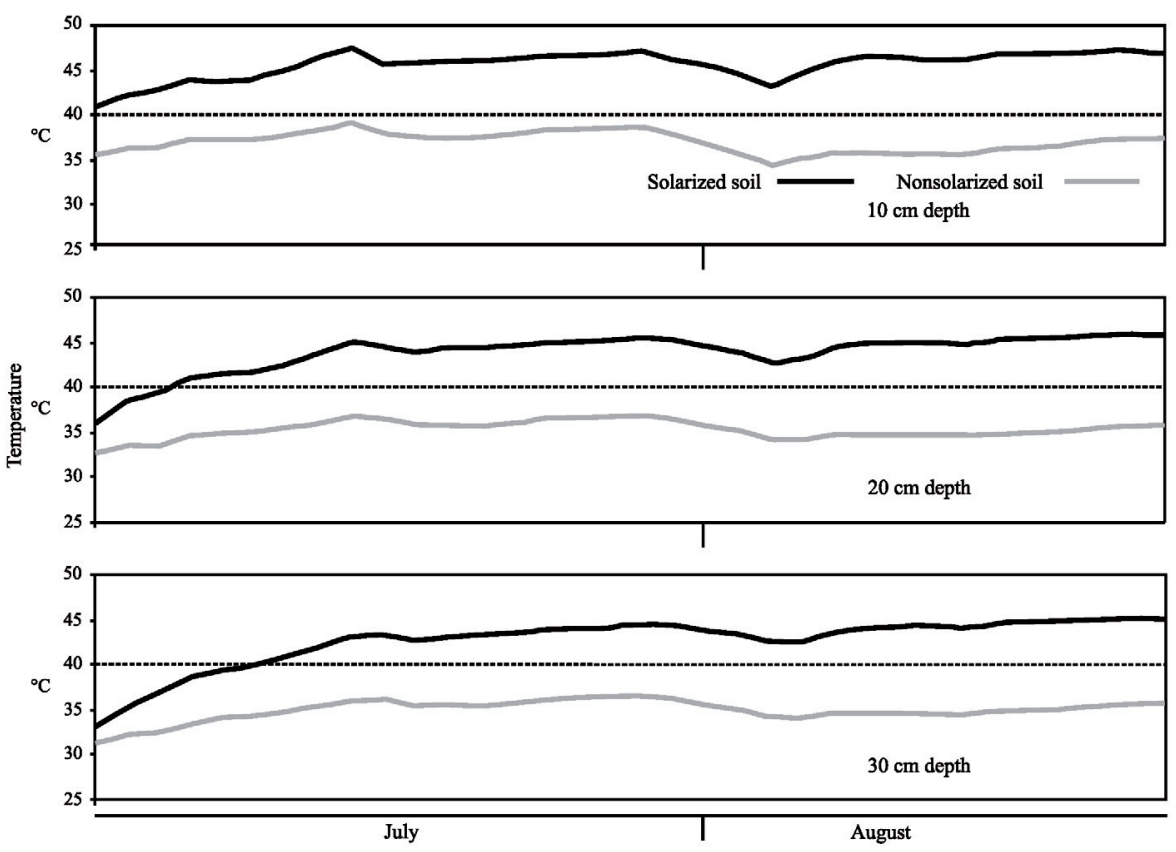

Figure 4. Daily mean soil temperatures at 10, 20 and $30 \mathrm{~cm}$ depth during solarization in 2000.

$6.0^{\circ} \mathrm{C}$, respectively, at 10,20 and $30 \mathrm{~cm}$ depth, being more evident only from the beginning of August onwards. Maximum temperatures were $47.3,45.2$ and $43.9{ }^{\circ} \mathrm{C}$ in solarized soil, and $39.4,37.9$ and $36.9^{\circ} \mathrm{C}$ in nonsolarized soil, respectively, at 10,20 and $30 \mathrm{~cm}$ depth. In 2000 average daily temperature values were $46.0,44.1$ and $42.5{ }^{\circ} \mathrm{C}$ in solarized soil and $37.0,35.5$ and $34.8{ }^{\circ} \mathrm{C}$ in nonsolarized soil, with an average difference of $9.0,8.6$ and $7.7{ }^{\circ} \mathrm{C}$ at 10,20 and $30 \mathrm{~cm}$ depth, respectively (Fig. 4). As in 1999, differences were larger at the end of the solarization period. Temperature peaks were 47.9, 46.2 and $45.1{ }^{\circ} \mathrm{C}$ in solarized soil, and $39.1,37.1$ and $36.5^{\circ} \mathrm{C}$ in nonsolarized soil, respectively, at 10,20 and $30 \mathrm{~cm}$ depth.

Soil temperatures at $0-30 \mathrm{~cm}$ depth exceeded values estimated as effective for suppression of most soil pathogens only in the first 40 days of solarization. $\mathrm{LD}_{95}$ values of 813,281 and 32.4 min at 39,42 , and $46{ }^{\circ} \mathrm{C}$, respectively, were found for the root-knot nematode $M$. incognita Kofoid et White Chitw. after the application of constant temperature-time dosages to infested soil (Ruiz et al., 2003), whereas a 30-min exposure at $60{ }^{\circ} \mathrm{C}$ was reported to be lethal for the potato cyst-nematode Globodera rostochiensis Wollenweber (Evans, 1991). LD $\mathrm{L}_{50}$ was found at 50 to $66{ }^{\circ} \mathrm{C}$ at 12 hours of exposure for eight common weed seeds (Egley, 1990), and a 30-min exposure at a 30 to $90^{\circ} \mathrm{C}$ range of temperatures decreased Cyperus rotundus L. tuber viability in an inverse linear manner (Rubin and Benjamin, 1984). Number of hours of lethal temperatures depends on seasonal weather conditions, but effectiveness of the treatment can also be related to other factors, including soil structure, color, organic matter content and seedbed preparation (Grinstein and Hetzroni, 1991).

\subsection{Effect on yield response}

Melon following solarization in 1998 showed significantly higher yield $(+116 \%)$ and fruit soluble solids content $(+25 \%)$ and a lower mean fruit weight $(-6 \%)$ in solarized than in nonsolarized plots (Tab. I). Compared with the control, a single solarization treatment in 1998 resulted in significantly higher yield $(+131 \%)$ and mean fruit weight $(+62 \%)$ and lower soluble solids content $(-23 \%)$ in the 1999 tomato crop, but yield parameters were not significantly different in the 2000 tomato crop or in melon in either 2000 or 2001 . Tomato and melon yields were significantly higher in plots solarized for two $(+284 \%$ and $+162 \%$, respectively, in tomato and melon) or three consecutive years $(+263$ and $+368 \%)$ than in nonsolarized plots, due to a higher number of heavier fruits per plant (Tab. II). Yield parameters of two- and three year-solarized plots did not significantly differ, either in tomato or melon. Soluble solids content of fruits from two- and three yearsolarized soil was always significantly higher than in nonsolarized plots in melon and lower in tomato, whereas no significant differences were found between the two- and three-yeartreatments.

Larger fruit size and consequent higher water content can explain the lower soluble solids content of tomato fruits from solarized soil, whereas the higher soluble solids content of melon fruits was due to the presence of larger plants bearing a higher number of smaller size fruits consequent to the growth stimulation effect of solarization. Irregular ripening following early nematode attack and plant collapse may explain the low quality of melon fruits from nonsolarized plots. The beneficial effect of thermal treatment on crop yield can be related not only to the suppression of nematodes and weeds, but also 
Table I. Residual effect of soil solarization performed in 1998 on yield parameters of the following tomato and melon crops.

\begin{tabular}{|c|c|c|c|c|c|c|c|c|c|c|c|c|c|c|c|c|}
\hline \multirow{3}{*}{ Solarization treatments } & \multicolumn{8}{|c|}{ Marketable yield } & \multicolumn{8}{|c|}{ Fruit quality } \\
\hline & \multicolumn{4}{|c|}{$\begin{array}{l}\text { Weight } \\
\left(\mathrm{t} \mathrm{ha}^{-1}\right)\end{array}$} & \multicolumn{4}{|c|}{$\begin{array}{l}\text { Fruits per } \\
\text { plant (n.) }\end{array}$} & \multicolumn{4}{|c|}{$\begin{array}{c}\text { Mean weight } \\
(\mathrm{g})\end{array}$} & \multicolumn{4}{|c|}{$\begin{array}{c}\text { Soluble solids } \\
\left({ }^{\circ} \text { Brix }\right)\end{array}$} \\
\hline & \multicolumn{2}{|c|}{ Tomato } & \multicolumn{2}{|c|}{ Melon } & \multicolumn{2}{|c|}{ Tomato } & \multicolumn{2}{|c|}{ Melon } & \multicolumn{2}{|c|}{ Tomato } & \multicolumn{2}{|c|}{ Melon } & \multicolumn{2}{|c|}{ Tomato } & \multicolumn{2}{|c|}{ Melon } \\
\hline & \multicolumn{16}{|c|}{ March 1999-July 1999} \\
\hline Nonsolarized & - & - & 17.7 & $\mathrm{~b}$ & - & - & 2.5 & $\mathrm{~b}$ & - & - & 1480 & $\mathrm{a}$ & - & - & 9.3 & b \\
\hline \multirow[t]{2}{*}{ Solarized } & - & - & 38.2 & $\mathrm{a}$ & - & - & 5.1 & $\mathrm{a}$ & - & - & 1390 & $\mathrm{~b}$ & - & - & 11.6 & $\mathrm{a}$ \\
\hline & \multicolumn{16}{|c|}{ August 1999-June 2000} \\
\hline Nonsolarized & 8.1 & $\mathrm{~b}$ & 11.2 & ns & 4.2 & $\mathrm{~b}$ & 1.7 & ns & 65 & $\mathrm{~b}$ & 1320 & ns & 4.7 & $\mathrm{a}$ & 8.6 & ns \\
\hline \multirow{2}{*}{ Solarized } & 18.7 & a & 13.2 & ns & 6.5 & a & 2.1 & $\mathrm{~ns}$ & 105 & $\mathrm{a}$ & 1130 & ns & 3.6 & $\mathrm{~b}$ & 9.0 & ns \\
\hline & \multicolumn{16}{|c|}{ August 2000-July 2001} \\
\hline Nonsolarized & 16.6 & ns & 10.8 & ns & 6.1 & ns & 1.5 & ns & 81 & $\mathrm{~ns}$ & 1920 & ns & 5.5 & $\mathrm{a}$ & 9.8 & ns \\
\hline Solarized & 10.3 & ns & 14.4 & ns & 4.0 & ns & 1.5 & ns & 76 & ns & 1960 & ns & 4.9 & $b$ & 10.0 & ns \\
\hline
\end{tabular}

Means followed by different letters in the same column within each crop cycle are statistically different at P $\leq 0.05$ (Student's $t$ Test).

Table II. Effect of soil solarization repeated for two or three consecutive years on yield parameters of tomato and melon crops.

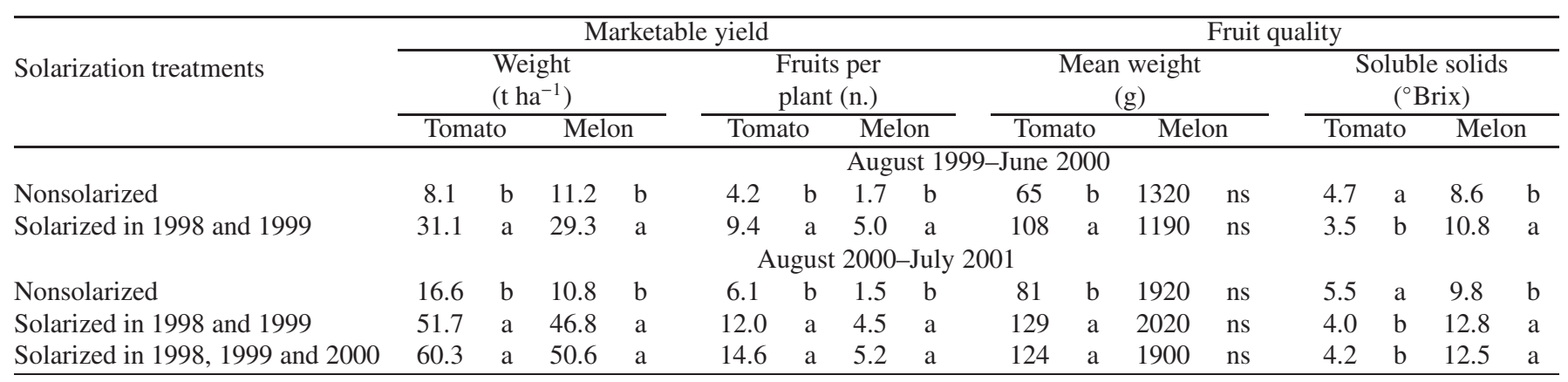

Means followed by different letters in the same column within each crop cycle are statistically different at P $\leqslant 0.05$ (Student's $t$ Test in $1999-$ 2000; Fisher's LSD Test in 2000-2001).

to the release of nutrients induced by high soil temperatures (Stapleton and DeVay, 1984), and/or to the suppression of other soil pathogens not evaluated in this experiment.

The residual effect of solarization on crop yield was extended to the two crop cycles immediately following the treatment. An increase in cotton crop yield was observed for as long as 3 years after a soil solarization treatment in Israel (Katan et al., 1983), and a high residual effect of an 8-week solarization was also found in a greenhouse experiment carried out in Cyprus (Ioannou, 2000).

\subsection{Effect on nematode population}

Tomato and melon roots from nonsolarized soil were severely infested by $M$. javanica in all crop cycles (Tabs. III, IV). Plots solarized in 1998 showed a strong reduction of the percentage of infected plants $(-99 \%)$ and severity of root galling $(-98 \%)$ in the following melon crop (Tab. III). Compared with the control, the single solarization treatment in 1998 resulted in a significantly lower number of root galls only in the 1999 tomato crop $(-22 \%)$, whereas number of galls and percent infected plants were not significantly different in the 2000 tomato crop or in melon in either 2000 or 2001. Percentages of infected plants and the root gall index were al- ways significantly $(P \leq 0.05)$ lower in soil solarized for two or three consecutive years than in untreated plots, both in tomato and melon crops (Tab. IV). Nematode infestation parameters were significantly lower $(-61 \%$ and $-70 \%$, respectively, for infected plant percentage and root gall index) in three-year solarized plots than in two-year treated soil only in melon in 2001, whereas no significant difference was found in tomato in 2000 .

Previous evidence was confirmed by the limited soil solarization effect on root-knot nematodes that emerged from this study. In the above cited greenhouse experiment in Cyprus soil, 8-week solarization reduced root-knot nematode infestation on tomato by only $50 \%$ (Ioannou, 2000). The effectiveness of the heat treatment may change for different target nematodes, as lethal temperatures and exposure times were found to be related to nematode species (D'Addabbo et al., 2005; Greco et al., 1998). Combination with pre- or post-plant nematicide applications or integration with other nonchemical techniques may enhance the nematicidal effect of solarization. Combination of 7-day soil solarization with reduced dosages of 1,3-dichloropropene significantly reduced root-knot nematode populations in tomato and pepper (Capsicum annuum L.) crops when compared with an untreated control (Chellemi and Mirusso, 2006). A 30-day soil solarization combined with 
Table III. Residual effect of soil solarization performed in 1998 on the infestation of Meloidogyne javanica in tomato and melon crops.

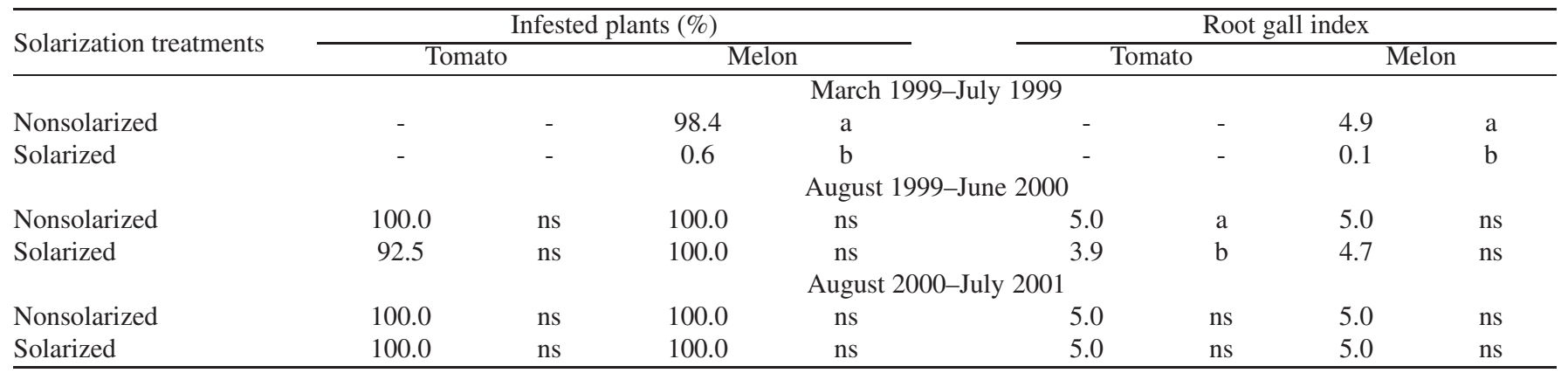

Means followed by different letters in the same column within each crop cycle are statistically different at $P \leq 0.05$ (Student's $t$ Test).

Table IV. Effect of soil solarization repeated for two or three consecutive years on the infestation of Meloidogyne javanica in tomato and melon crops.

\begin{tabular}{|c|c|c|c|c|c|c|c|c|}
\hline \multirow{2}{*}{ Solarization treatments } & \multicolumn{4}{|c|}{ Infested plants (\%) } & \multicolumn{4}{|c|}{ Root gall index } \\
\hline & \multicolumn{2}{|c|}{ Tomato } & \multicolumn{2}{|c|}{ Melon } & \multicolumn{2}{|c|}{ Tomato } & \multicolumn{2}{|c|}{ Melon } \\
\hline & & & & gus & & & & \\
\hline \multirow{3}{*}{$\begin{array}{l}\text { Nonsolarized } \\
\text { Solarized in } 1998 \text { and } 1999\end{array}$} & 100.0 & a & 100.0 & $\mathrm{a}$ & 5.0 & $\mathrm{a}$ & 5.0 & $\mathrm{a}$ \\
\hline & 0.0 & $\mathrm{~b}$ & 14.3 & $\mathrm{~b}$ & 0.0 & $\mathrm{~b}$ & 0.7 & $\mathrm{~b}$ \\
\hline & \multicolumn{8}{|c|}{ August 2000-July 2001} \\
\hline Nonsolarized & 100.0 & a & 100.0 & $\mathrm{a}$ & 5.0 & $\mathrm{a}$ & 5.0 & $\mathrm{a}$ \\
\hline Solarized in 1998 and 1999 & 3.3 & $\mathrm{~b}$ & 54.4 & $\mathrm{~b}$ & 0.3 & $\mathrm{~b}$ & 2.3 & $\mathrm{~b}$ \\
\hline Solarized in 1998,1999 and 2000 & 0.0 & $\mathrm{~b}$ & 21.4 & $\mathrm{c}$ & 0.0 & $\mathrm{~b}$ & 0.7 & $\mathrm{c}$ \\
\hline
\end{tabular}

Means followed by different letters in the same column within each crop cycle are statistically different at $P \leq 0.05$ (Student's $t$ Test in 1999-2000; Fisher's LSD Test in 2000-2001).

organic amendments was more effective than solarization or amendments alone at reducing $M$. incognita and $M$. javanica populations in soil and galling indices on tomato and pepper plants (Oka et al., 2007).

Rapid soil recolonization by nematodes after the thermal treatment is the main reason for the short residual effect of solarization on root-knot nematodes, as $M$. javanica infestation on tomato cultivated only one year later was slightly affected by solarization performed in the previous year. The beneficial effect of solarization on nematodes can be enhanced by repeating thermal treatment for two or three consecutive years, as continuous solarization treatments do not allow the recolonization of soil by nematodes and progressively reduce population densities to under the economic threshold. In our experiment, two consecutive solarization treatments resulted in almost gall-free tomato plants and the nematicidal effect was further increased by a third solarization cycle.

\subsection{Effect on weeds}

At the end of solarization in 1998 only C. rotundus L. survived under the plastic film, whereas uncovered plots were infested by many annual and perennial weeds, with a prevalence of $C$. rotundus and Cynodon dactylon (L.) Pers. (Tab. V). In the solarized soil, emergence of annual weeds was completely suppressed at the end of the subsequent melon crop, and only $C$. rotundus, $C$. dactylon (at a density significantly lower than in the nonsolarized soil) and Phragmites australis (Cav.) Trin. were found. In soil solarized only in 1998, several species were found before tomato transplanting in 1999, but the density of $C$. dactylon, Digitaria sanguinalis (L.) Scop., Echinochloa crus-galli L. Beauv. and Portulaca oleracea L. was significantly lower than in nonsolarized soil (Tab. VI). The density of $C$. dactylon and $D$. sanguinalis was also significantly reduced following tomato in 1999 and after solarization in 2000. Emergence of annual weeds was also significantly lower or completely suppressed in melon in 2000, whereas only the density of $C$. dactylon was significantly lower after tomato in 2000 and melon in 2001. Soil treated for two consecutive years was completely free of weeds after the second treatment in 1999, and few weed species were present also in the following tomato, with $C$. dactylon and D. sanguinalis showing a significantly lower density than in the control (Tab. VII). Melon transplanted in March 2000 was infested mostly by annual weeds, whose emergence, including $C$. rotundus, was significantly reduced or completely suppressed in the two-year solarized soil.

At the end of solarization in 2000 a significant suppression of weed emergence was found in soil solarized either for two or three consecutive years. The density of $C$. dactylon was significantly lower in solarized plots after the following tomato and melon crops, whereas the density of D. sanguinalis, $P$. oleracea and $S$. nigrum was significantly reduced only after 
Table V. Weed emergence in uncultivated soil and in melon crops after solarization in 1998 (plants $\mathrm{m}^{-2}$ ).

\begin{tabular}{|c|c|c|c|c|c|c|c|c|c|c|c|c|}
\hline \multirow{3}{*}{ Weed species } & \multicolumn{8}{|c|}{ No crop } & \multirow{2}{*}{\multicolumn{4}{|c|}{ Melon crop }} \\
\hline & \multicolumn{4}{|c|}{ October 1998} & \multicolumn{4}{|c|}{ February 1999} & & & & \\
\hline & \multicolumn{2}{|c|}{ nonsolarized } & \multicolumn{2}{|c|}{ solarized } & \multicolumn{2}{|c|}{ nonsolarized } & \multicolumn{2}{|c|}{ solarized } & \multicolumn{2}{|c|}{ nonsolarized } & \multicolumn{2}{|c|}{ solarized } \\
\hline \multicolumn{13}{|l|}{$\overline{\text { Perennial species }}$} \\
\hline Phragmites australis (Cav.) Trin. & 0.3 & a & 0.0 & $\mathrm{~b}$ & - & - & - & - & 1.7 & ns & 2.0 & $\mathrm{~ns}$ \\
\hline Cirsium arvense (L.) Scop. & - & - & - & - & 0.5 & $\mathrm{a}$ & 0.0 & $\mathrm{~b}$ & 3.0 & $\mathrm{a}$ & 0.0 & $\mathrm{~b}$ \\
\hline Cynodon dactylon (L.) Pers. & 1.5 & a & 0.0 & $\mathrm{~b}$ & - & - & - & - & 2.7 & a & 1.7 & $\mathrm{~b}$ \\
\hline Cyperus rotundus $\mathrm{L}$. & 2.3 & a & 1.5 & $\mathrm{~b}$ & - & - & - & - & 8.0 & a & 5.3 & $\mathrm{~b}$ \\
\hline \multicolumn{13}{|l|}{ Annual species } \\
\hline Setaria viridis (L.) Beauv. & - & - & - & - & - & - & - & - & 7.7 & a & 0.0 & $\mathrm{~b}$ \\
\hline Solanum nigrum $\mathrm{L}$. & - & - & - & - & - & - & - & - & 15.7 & a & 0.0 & $\mathrm{~b}$ \\
\hline Sonchus oleraceus L. & - & - & - & - & - & - & - & - & 1.7 & a & 0.0 & $\mathrm{~b}$ \\
\hline Echinochloa crus-galli (L.) Beauv. & 0.5 & a & 0.0 & $\mathrm{~b}$ & 1.8 & a & 0.0 & $\mathrm{a}$ & 5.0 & a & 0.0 & $\mathrm{~b}$ \\
\hline Portulaca oleracea $\mathrm{L}$. & 0.5 & a & 0.0 & $\mathrm{~b}$ & - & - & - & - & - & - & - & - \\
\hline Heliotropium europaeum L. & 0.3 & a & 0.0 & $\mathrm{~b}$ & - & - & - & - & - & - & - & - \\
\hline Euphorbia sp. & 0.5 & $\mathrm{a}$ & 0.0 & $\mathrm{~b}$ & - & - & - & - & - & - & - & - \\
\hline Vicia sativa $\mathrm{L}$ & - & - & - & - & 150 & $\mathrm{a}$ & 20.0 & $\mathrm{~b}$ & 6.0 & a & 0.0 & $\mathrm{~b}$ \\
\hline Melilotus sulcatus L. & - & - & - & - & - & - & - & - & 2.3 & a & 0.0 & $\mathrm{~b}$ \\
\hline Chenopodium album L. & - & - & - & - & - & - & - & - & 3.3 & $\mathrm{a}$ & 0.0 & $\mathrm{~b}$ \\
\hline Amaranthus retroflexus L. & - & - & - & - & - & - & - & - & 2.7 & $\mathrm{a}$ & 0.0 & $\mathrm{~b}$ \\
\hline
\end{tabular}

Means followed by different letters in the same row within each observation date are statistically different at $P \leq 0.05$ (Student's $t$ Test).

Table VI. Residual effect of soil solarization performed in 1998 on weed emergence in the following tomato and melon crops (plants $\mathrm{m}^{-2}$ ).

\begin{tabular}{|c|c|c|c|c|c|c|c|c|c|c|c|c|}
\hline \multirow{3}{*}{ Weed species } & \multicolumn{4}{|c|}{ No crop $^{(1)}$} & \multicolumn{4}{|c|}{ Tomato } & \multicolumn{4}{|c|}{ Melon } \\
\hline & \multicolumn{2}{|c|}{ nonsolarized } & \multicolumn{2}{|c|}{ solarized } & \multicolumn{2}{|c|}{ nonsolarized } & \multicolumn{2}{|c|}{ solarized } & \multicolumn{2}{|c|}{ nonsolarized } & \multicolumn{2}{|c|}{ solarized } \\
\hline & \multicolumn{12}{|c|}{ August 1999-June 2000} \\
\hline \multicolumn{13}{|l|}{ Perennial species } \\
\hline Cynodon dactylon (L.) Pers. & 21.0 & $\mathrm{a}$ & 1.5 & $\mathrm{~b}$ & 2.6 & $\mathrm{a}$ & 1.3 & $\mathrm{~b}$ & 3.0 & $\mathrm{a}$ & 1.7 & $\mathrm{~b}$ \\
\hline \multicolumn{13}{|l|}{ Annual species } \\
\hline Digitaria sanguinalis (L.) Scop. & 34 & $\mathrm{a}$ & 10.5 & $\mathrm{~b}$ & 3.3 & a & 0.3 & $\mathrm{~b}$ & 6.6 & $\mathrm{a}$ & 2.0 & $\mathrm{~b}$ \\
\hline Echinochloa crus-galli (L.) Beauv. & 49 & $\mathrm{a}$ & 0.0 & $\mathrm{~b}$ & - & - & - & - & 6.2 & $\mathrm{a}$ & 0.4 & $\mathrm{~b}$ \\
\hline Portulaca oleracea $\mathrm{L}$. & 76.0 & a & 21.0 & $\mathrm{~b}$ & - & - & - & - & 1.2 & $\mathrm{a}$ & 0.6 & $\mathrm{~b}$ \\
\hline \multirow[t]{2}{*}{ Others $^{(2)}$} & - & - & - & - & - & - & - & - & 1.4 & ns & 0.7 & $\mathrm{~ns}$ \\
\hline & \multicolumn{12}{|c|}{ August 2000-July 2001} \\
\hline \multicolumn{13}{|l|}{ Perennial species } \\
\hline Cynodon dactylon (L.) Pers. & 1.0 & $\mathrm{a}$ & 0.0 & $\mathrm{~b}$ & - & - & - & - & 2.4 & ns & 1.2 & $\mathrm{~ns}$ \\
\hline $\begin{array}{l}\text { Cyperus rotundus } \mathrm{L} \text {. } \\
\text { Annual species }\end{array}$ & 8.0 & ns & 11.3 & ns & 1.0 & ns & 1.3 & ns & 8.8 & ns & 7.5 & ns \\
\hline Digitaria sanguinalis (L.) Scop. & 26.0 & $\mathrm{a}$ & 4.7 & $\mathrm{~b}$ & 1.2 & ns & 0.6 & ns & 173.6 & $\mathrm{a}$ & 60.2 & $\mathrm{~b}$ \\
\hline Portulaca oleracea L. & 22.3 & ns & 14.7 & ns & - & - & - & - & 13.6 & ns & 9.8 & ns \\
\hline Solanum nigrum L. & - & - & - & - & - & - & - & - & 13.6 & $\mathrm{a}$ & 2.0 & $\mathrm{~b}$ \\
\hline
\end{tabular}

Means followed by different letters in the same row within each observation date are statistically different at $P \leq 0.05$ (Student's $t$ Test); (1) before tomato transplanting; (2) including Setaria viridis (L.) Beauv., Amaranthus retroflexus L., Solanum nigrum L. and Chenopodium album L.

melon (Fig. 5). No suppressive effect of the two- and threeyear solarization treatments was found on $C$. rotundus.

In previous trials, 98-day soil solarization reduced weeds present in collard green (Brassica oleracea acephala L.) by 91\% and increased crop yield in the following year, being more effective than a herbicide treatment (Stevens et al., 1990). In another experiment in Syria, 50-day solarization reduced total weed density by $80 \%$ and total weed biomass by 94 and $85 \%$ in lentil and faba bean, respectively (Linke, 1994). Tolerance of $C$. rotundus and high susceptibility of $C$. dacty- lon to solarization were also reported (Rubin and Benjamin, 1984). Weed suppression was probably also affected by the stimulating effect of solarization on crop growth, that likely resulted in a higher competitive ability of tomato and melon crop stands in solarized soil. Moreover, seasonal climate and cultural practices may also influence weed species composition and density.

The long-term effect of single soil solarization was much more pronounced on weeds than on nematodes, since a reduction or a total suppression of annual species and some 
V. Candido et al.

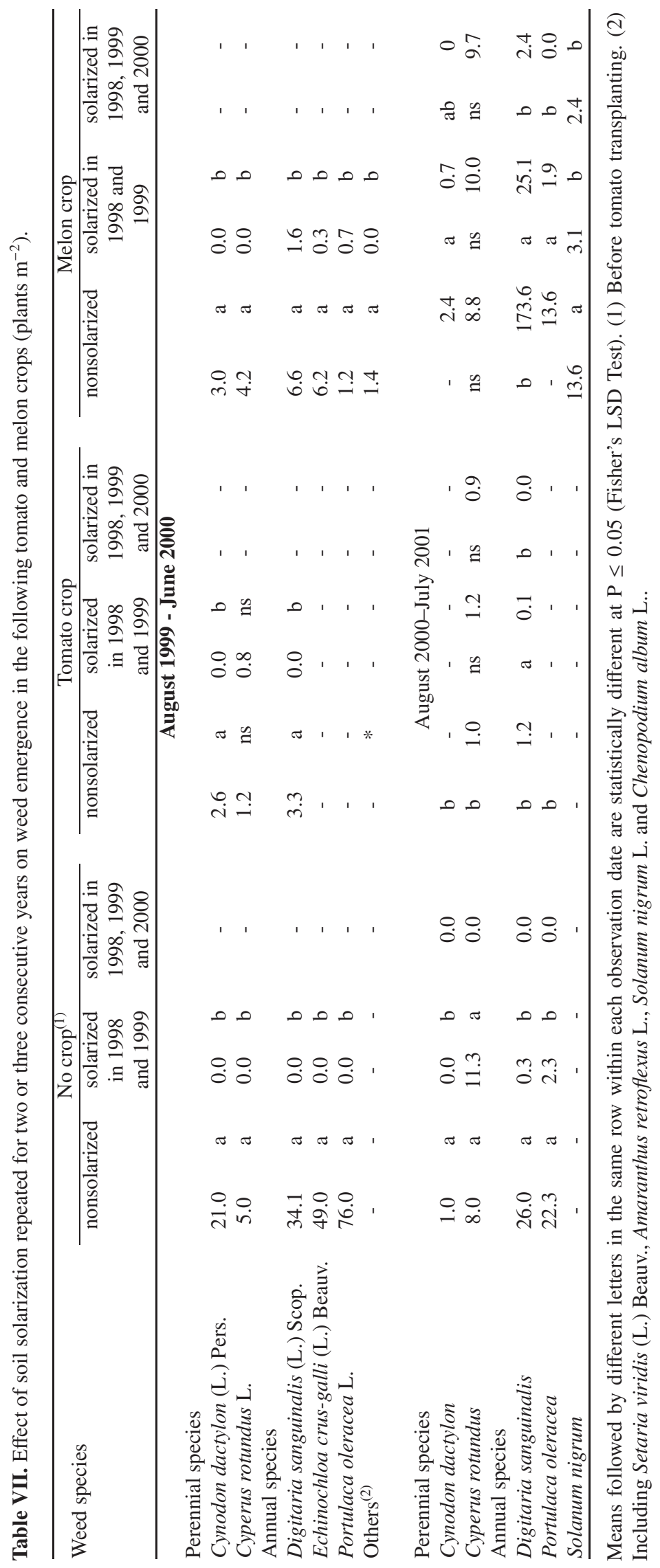




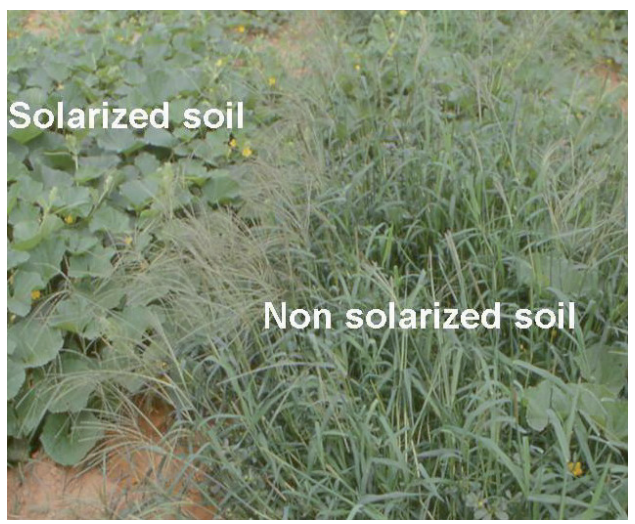

Figure 5. Weed emergence in 2001 melon crop.

perennial species were still found on melon cultivated after two years, and also later for $C$. dactylon. In a previous experiment 5-week solarization maintained soil free of weeds for at least three years in an olive orchard (Lopez-Escudero and Blanco-Lopez, 2001). The effects of repeated solarization were less evident on weeds due to the prolonged residual effect of single treatment.

Soil solarization was confirmed as a valid tactic for management of root-knot nematodes and weeds in the greenhouse. Limits to a further diffusion of this technique are still represented by treatment duration and final disposal of the plastic film. Integration with reduced amounts of chemicals may shorten the solarization period without reducing its efficacy (Benlioglu et al., 2005; Chellemi et al., 1997; Minuto et al., 2000), whereas use of innovative biodegradable or photodegradable films (Castronuovo et al., 2005) may combine thermal performance on nematodes and weeds and yield increase with a simple and environmentally safer plastic disposal.

\section{CONCLUSION}

Under the warm weather conditions of Southern Italy, solarization is an effective technique for an environmentally sustainable and cost-saving disinfestation of soil in greenhouse cropping systems, providing a satisfactory control of most weeds and a sufficient short-term nematode suppression. Progressive phasing out of most of the presently available chemicals and heavier root-knot nematode infestations that are likely to occur in warmer summer seasons will further enhance the importance of this technique in the near future. Two- or threeyearly treatments can be enough for an effective control of weeds, whereas annual treatments are required for nematodes. Use of high thermal-efficiency films or combination with low doses of chemicals or other nonchemical methods can prolong the residual effects of single solarization on nematodes. Solarization repeated for two consecutive years can considerably enhance the effect on nematodes and crop yield. Application of an additional treatment in the third year results in no further improvement.
Acknowledgements: This work was carried out within the research project "Innovative and eco-compatible technologies for extra-seasonal and quality vegetable production" (TEPORE), POM Measure 2. The authors shared the work equally.

\section{REFERENCES}

Benlioglu S., Boz A., Yildiz G., Benlioglu K. (2005) Alternative soil solarization treatments for the control of soil-borne diseases and weeds of strawberry in the Western Anatolia of Turkey, J. Phytopathol. 153, 423-430.

Camprubí A., Estaún V., El Bakali M.A., Garcia-Figueres F., Calvet C. (2007) Alternative strawberry production using solarization, metham sodium and beneficial soil microbes as plant protection methods, Agron. Sustain. Dev. 27, 179-184.

Castronuovo D., Candido V., Margiotta S., Manera C., Miccolis V., Basile M., D'Addabbo T. (2005) Potential of a corn starch-based biodegradable plastic film for soil solarization, Acta Hort. (ISHS) 698, 201-206.

Chellemi D.O., Mirusso J. (2006) Optimizing Soil Disinfestation Procedures for Fresh Market Tomato and Pepper Production, Plant Dis. 90, 668-674.

Chellemi D.O., Olson S.M., Mitchell D.J., Secker I., McSorley R. (1997) Adaptation of soil solarization to the integrated management of soilborne pests of tomato under humid conditions, Phytopathology $87,250-258$.

D’Addabbo T., Sasanelli N., Greco N., Stea V., Brandonisio A. (2005) Effect of water, soil temperatures and exposure times on the survival of the sugar beet cyst nematode, Heterodera schachtii, Phytopathology 4, 339-344.

Egley G.H. (1990) High-temperature effects on germination and survival of weed seeds in soil, Weed Sci. 38, 429-435.

Evans K. (1991) Lethal temperatures for eggs of Globodera rostochiensis, determined by staining with New Blue R, Nematologica 37, 225229.

Freeman S., Sztejnberg A., Shabi E., Katan J. (1990) Long-term effect of soil solarization for the control of Rosellinia necatrix in apple, Crop Prot. 9, 312-316.

Greco N., D’Addabbo T., Sasanelli N., Senhorst J.W., Stea V., Brandonisio A. (1998) Effect of temperature and exposure times on the mortality of the carrot cyst nematode Heterodera carotae, Int. J. Pest Manage. 44, 99-107.

Grinstein A., Hetzroni A. (1991) The technology of soil solarization, in: Katan J., DeVay J.E. (Eds.), Soil Solarization, CRC Press, Boca Raton, Florida, USA, pp. 159-170.

Ioannou N. (2000) Soil solarization as a substitute for methyl bromide fumigation in greenhouse tomato production in Cyprus, Phytoparasitica 28, 248-256.

Katan J. (1999) The methyl bromide issue: problems and potential solutions, J. Plant Pathol. 81, 153-159.

Katan J., Fishler G., Grinstein A. (1983) Short and long term effects of soil solarization and crop sequence on Fusarium wilt and yield of cotton in Israel, Phytopathology 73, 1215-1219.

Kolberg R.L., Wiles L.J. (2002) Effect of steam application on cropland weeds, Weed Technol. 16, 43-49.

Linke K.H. (1994) Effects of soil solarization on arable weeds under Mediterranean conditions: control, lack of response or stimulation, Crop Prot. 13, 115-120.

Lopez-Escudero F.J., Blanco-Lopez M.A. (2001) Effect of a single or double soil solarization to control Verticillium wilt in estabilished olive orchards in Spain, Plant Dis. 85, 489-496. 
Luvisi A., Materazzi A., Triolo E. (2006) Steam and exothermic reactions as alternative techniques to control soil-borne diseases in basil, Agron. Sustain. Dev. 26, 201-207.

Minuto A., Gilardi G., Gullino M.L., Garibaldi A. (2000) Combination of soil solarization and dazomet against soilborne pathogens of glasshouse-grown basil, tomato and lettuce, Acta Hort. (ISHS) 532, $165-170$.

Nico A.I., Jiménez-Díaz R.M., Castillo P. (2003) Solarization of soil in piles for the control of Meloidogyne incognita in olive nurseries in southern Spain, Plant Pathol. 52, 770-778.

Oka Y., Shapira N., Fine P. (2007) Control of root-knot nematodes in organic farming systems by organic amendments and soil solarization, Crop Prot. 26, 1556-1565.

Roe N., Ozores-Hampton M., Stansly P.A. (2004) Solarization effects on weed populations in warm climates, Acta Hort. (ISHS) 638, $197-$ 200

Rubin B., Benjamin A. (1983) Solar heating of the soil: effect on weed control and on soil-incorporated herbicides, Weed Sci. 31, 819-825.

Rubin B., Benjamin A. (1984) Solar heating of the soil: involvement of environmental factors in the weed control process, Weed Sci. 32, $138-142$.

Russo G., Candura A., Scarascia-Mugnozza G. (2005) Soil solarization with biodegradable plastic film: two years of experimental tests. Acta Hort. (ISHS) 691, 717-724.

Ruiz T.S., Stapleton J.J., McKenry M.V. (2003) Lethal temperature-time dosages for Meloidogyne incognita, in: Proceedings of the 2003
Annual International Research Conference on Methyl Bromide Alternatives and Emissions Reductions, San Diego, CA, USA, November 3-6, 2003, pp. 137-1-137-2.

Shlevin E., Saguy I.S., Mahrer Y., Katan J. (2003) Modeling the survival of two soilborne pathogens under dry structural solarization, Phytopathology 93, 1247-1257.

Stapleton J.J. (2000) Soil solarization in various agricultural production systems, Crop Prot. 19, 837-841.

Stapleton J.J., DeVay J.E. (1995) Soil solarization: A natural mechanism of integrated pest management, in: Reuveni R. (Ed.), Novel Approaches to Integrated Pest Management, Lewis Publishers, Boca Raton, Florida, USA, pp. 309-322.

Stapleton J.J., DeVay J.E. (1984) Thermal components of soil solarization as related to changes in soil and root microflora and increased plant growth response, Phytopathology 74, 255-259.

Stevens C., Khan V.A., Okoronkwo T., Tang A.Y., Wilson M.A., Lu J. (1990) Soil solarization and Dacthal: influence on weeds, growth, and root microflora of collards, Hort Science 25, 1260-1262.

Taylor A.L., Sasser J.N. (1987) Biology, Identification and Control of Root-knot Nematodes (Meloidogyne species), North Caroline State University Graphics, Raleigh, North Caroline, USA.

Tjamos E.C., Paplomatas E.J. (1988) Long-term effect of soil solarization in controlling Verticillium wilt of globe artichokes in Greece, Plant Pathol. 37, 507-515. 